\title{
Essay \\ Re-Assembling Anti-Oppressive Practice (1): The Personal, the Political, the Professional
}

\author{
Janet Batsleer
}

check for

updates

Citation: Batsleer, J. Re-Assembling Anti-Oppressive Practice (1): The Personal, the Political, the Professional. Educ. Sci. 2021, 11, 645. https:// doi.org/10.3390/educsci11100645

Academic Editors: Pam Alldred and Frances Howard

Received: 15 June 2021

Accepted: 7 October 2021

Published: 14 October 2021

Publisher's Note: MDPI stays neutral with regard to jurisdictional claims in published maps and institutional affiliations.

Copyright: (C) 2021 by the author. Licensee MDPI, Basel, Switzerland. This article is an open access article distributed under the terms and conditions of the Creative Commons Attribution (CC BY) license (https:// creativecommons.org/licenses/by/ $4.0 /)$.
Education and Social Research Institute, Manchester Metropolitan University, Manchester M15 5RN, UK; J.Batsleer@mmu.ac.uk

\begin{abstract}
This essay offers a broken narrative concerning the early history of anti-oppressive practice as an approach in the U.K. to youth and community work and the struggles over this in the context of UK higher education between the 1960's and the early 2000's. Educating informal educators as youth and community workers in the UK has been a site of contestation. Aspects of a genealogy of that struggle are presented in ways which link publicly available histories with personal memories and narratives, through the use of a personal archive developed through collective memory work. These are chosen to illuminate the links between theory and practice: on the one hand, the conceptual field which has framed the education of youth and community workers, whose sources lie in the academic disciplines of education and sociology, and, on the other hand, the social movements which have formed the practice of informal educators. Six have been chosen: (1) The long 1968: challenging approaches to authority; (2) the group as a source of learning; (3) The personal and political: experiential learning from discontent; (4) Paolo Freire and Critical Praxis; (5) A critical break in social education and the reality of youth work spaces as defensive spaces; (6) New managerialism: ethics vs. paper trails. The approach taken, of linking memory work with present struggles, is argued to be a generative form for current critical and enlivening practice.
\end{abstract}

Keywords: anti-oppressive practice; social movements; critical praxis; youth and community work; critical pedagogy

\section{Introduction}

This article forms a very partial account of the experience of offering professional formation in 'anti-oppressive practice' in youth and community work in the period from the mid-1980's to around the turn of the twenty-first century. The term 'anti-oppressive practice' distinguished from the more liberal term 'anti-discriminatory practice' emerged in the 1980's as a challenge, in the fields of social work, youth work and community development, to forms of practice which ignored power relations, especially the impact of the class system and of patterns of racism and sexism. In what follows, the emergence of the term in the field of education of youth and community workers in higher education in the UK is traced in a very partial history. The term arose and became a focus of practice in the 1980's, which has been called the period of 'the politicised years' [1]. It was later codified in particular in social work text books, especially in the popular 'Anti-Discriminatory Practice' [2], which offered an analysis of power and oppression through personal, cultural and structural lenses. It was during this same period that the term 'Informal Education' became well established as a generic term for youth work in the UK, replacing to some extent the earlier terminology of social education, largely thanks to the work of Mark Smith and Tony Jeffs [3].

I first attended a youth club and a youth arts project in the early 1970's; I became a part-time worker on Adventure Playgrounds, and then a full-time youth and community worker. In 1986 I started working at Manchester Polytechnic as a lecturer in youth and community work. I continued in that work until retiring from Manchester Metropolitan 
University in 2020, having been part of the UK Youth Work world and educated informal educators throughout that long period. However, I believe this holds much more than merely personal interest, as the trajectory of our work was shaped first by the sense of the 'long 1968' and its influence [4], and then by the post-1989 period of 'capitalist realism' [5], with the hegemonic conviction that 'there is no alternative' to neoliberal economics and forms of education which credentialise and turn students into consumers, only to hold them entirely responsible, in a sickening manner, for their own failures within the education system. This post-1989 turn became linked to an audit culture from which we still need to devise ever more creative methods of escape. The ethical and political imperatives associated with 'anti-oppressive practice' remain in contradiction with the imperatives of 'capitalist realism' in both universities and many contemporary forms of youth work practice. The aspects of educating informal educators presented here follow an arc leading from optimism to a deadening kind of inertia: but they also provoke an awareness of the possibility of a different kind of praxis.

My certainly unreliable memories of the earliest years of my work as a youth and community Work educator at Manchester Polytechnic/Manchester Metropolitan University were re-awakened by the participation in a collective biography project entitled 'Re-assembling Anti-Oppressive Practice' [6]. I have worked over many years with ideas from Frigga Haug's [7] 'memory work' method, which, alongside other 'consciousness raising' methods in both research and movement spaces, was important in the 1980's and continues to influence contemporary work on collective biography [8]. The process we undertook, like Haug's, prompted writing out of everyday memories and experiences of oppression which were then discussed in a group setting. This is the source of the writing presented here. We aimed to explore the theoretical significance of apparently mundane and everyday moments in the marginal and conflicted space of educating youth and community workers in UK higher education. In what follows I have chosen to offer accounts of particular concepts and practices in order to show a set of entanglements between the field of youth and community work, significant social movements of the second half of the twentieth century, and both State or market forms. I am drawing on lived experience and personal archives as well as on courses I have taught throughout the period from the 1970's to the early 2000's. Working with 'the archive' has become a significant method for enquiry into feminist education practices [9]. The idea of 'the archive' is that it does not provide neutral data, but forms part of a genealogy which can be generative of feminist practice in the here and now. It is for this reason that I draw on both established texts and personal memory in what follows, seeking to validate forms of knowing usually excluded from the written and academic record. This builds on work undertaken as part of the Feminist Webs archive collective [10]. In such an approach both marginality and marginalia become the strong thread of a continuously emergent practice.

There has long been a sense that youth and community work courses have offered a 'radical' space at the margins both of higher education and of the field of youth and community work, itself a practice marginal to the mainstream institutions of education and social care. This has been expressed both in terms of the courses being in tension with the requirements of higher education (for example through emphasising experience as much as academic qualifications in recruitment processes) and being criticised for remoteness from the field of practice as a result of an emphasis on the importance of a critical engagement with current policy directives, whatever their origin. At the heart of our discussions in the 'Re-assembling Anti-Oppressive Practice' collective has been the question of the extent to which this field of practice has been and may yet again become permeable to wider radical and democratic social movements and the pedagogies associated with them.

In this genealogy of 'anti-oppressive practice' (a term which emerged at a certain point and then almost disappeared, being replaced by terms such as 'inclusion' and 'equality and diversity') I have chosen to highlight both concepts and practices which show youth and community work in the UK to be a powerfully contested terrain. The term 'antioppressive practice' became a phrase which gathered those who experienced youth and 
community work as a site of struggle, especially for the rights of young people in relation to the oppressive forces of, for example, policing or schooling, and against practices of youth and community work which were primarily concerned with the social control of young people. As chair of the UK QAA Subject Benchmark process which established the framework for the recognition of undergraduate courses in this field, such contestation seemed to me to be of the utmost significance, even to the extent of defining the field [11]. The turn from the engagement with social movements to the development of bureaucratic forms of accountability in which 'anti-oppressive practice' became nothing more than a 'tick box' exercise is part of the sorry tale here, but it is the earlier lively struggles to which this essay draws attention. In the end, in the Benchmark process, the conflict took the form of an argument surrounding naming: whether the word 'community' belonged in the naming of this Benchmark at all. The term 'youth and community work' marked a pragmatic compromise, and so this genealogy, which begins with the term 'community' is not innocent. The word 'community', with its dangerous echoes of 'communism', could at times become a code for commitment to a grassroots practice with an ethic which promoted equality and social justice.

This genealogical approach is intended to suggest ways in which emerging conceptualisations, the spaces afforded by higher education, and a specific field of practice have overlapped with one another. It also offers a glimpse of how, in a very small field of practice, relations between individuals and patterns of influence emerge which are as significant as bodies of theory, and are intertwined with them. In particular, the role of individuals in the Training Agencies Group (TAG), the Trade Union (CYWU) and the Youth Work Unit at the National Youth Bureau (NYB/subsequently National Youth Agency/NYA) are the focus of attention. These have been important UK national reference points for the practice of youth and community work. In terms of Educating Informal Educators, the work of TAG, now the Professional Association of Lecturers in Youth and Community Work (PALYCW) is central to the story told here.

The sources and the methods here therefore intertwine the personal, the public and the political. The writing of the six aspects which follow engages with each of these sources. Where possible I have referenced both published texts and personal blogs and other communications. The rest relies on my own memories of the times.

\section{2. 'The Long 1968 ... ' and Changing Approaches to Authority}

The Milson-Fairbairn report, commissioned in 1969 [12] by a Labour government to explore links between youth work, schools and Further Education, on the one hand, and adult community groups, on the other, is much less discussed than the Albemarle Report (1960) [13], which is usually treated as the origin document for the formation of Youth Leadership as a profession. Yet this was the report that opened up a difficult, fruitful conversation between 'community development' (rooted in Christian traditions of 'overseas mission') and 'Youth Leadership' (also with strong roots in Christian philanthropy and yet based 'at home' and newly professionalised in the formation of the National College). It also opened the conversation between youth leadership (now termed youth and community work) and the development of democratic forums in formal education such as student unions. In 1969, in line with a salary scale which had long been applicable to 'Youth Leaders and Community Centre Wardens', community development joined counselling and group work as key elements in the curriculum for the training and development of such staff.

The term ' 1968 ' has come to represent a moment which in fact occurred both before and after 1968 and into the early 1970's, when many traditional hierarchies were being brought into question, not least in education and in the field of charitable endeavours. Paternalistic and patronising forms of practice were becoming increasingly difficult to sustain. Inherited patterns of authority were put strongly into question. 'The Laughter of Stafford Girls High' (as Carol Ann Duffy describes it in the wonderful poem of that name [14]) had been let loose in the world, and the 'youthquake' of that time was moving 
faster than any of the newly established youth and community work training courses could hope to capture.

Student movements were central to 'les évènements' of 1968, and movements to reform school education formed an inevitable counterpart to the attempt to reform universities. The student protests centred on the opposition to war, to militarism and to bureaucratic power, but also on the universities themselves, including the ways in which university authorities had repressed civil rights protests and disciplined those involved. In relation to schools, the example of the Little Red School Book [15] $(1969,2014)$, which presented an open educational approach for young people towards drugs (including tobacco and alcohol) and towards sex (including the discussion of female masturbation), became a cause célèbre for the Christian establishment across Europe to rally against. Opening up such liberalising conversations in Youth Work remained controversial well into the 1970's, so youth work was positioned as behind the curve and as an 'agent of social control' in a moment of youthful rupture against 'establishments' internationally. But courses in higher education settings did begin to open up the possibility of an engagement between youth and community work and the counterculture.

The non-judgmental ethos of the counterculture was present in the emphasis on the 'social' that had developed in both the training of youth leaders and the formation of community development workers. 'Social education' (as it was termed) might turn out to be more than an education in moral development, civilising behaviour and minding your 'p's and q's.' Ideas about 'group work', especially non-directive group work, and peer-led learning came to the fore. Ideas about community development as a form of activism allied to civil rights brought a sense of the politics of the time into recently established courses, which were still forging a sense of 'professionalism' in order to distinguish this practice from 'old style' philanthropy. However, this professionalism was, in its turn, problematic in its assumptions concerning a neutral 'expertise.'

As Stuart Hall and Tony Jefferson [16] made clear in their groundbreaking study 'Resistance through Rituals', the power of youth counterculture was only part of the story. Youth 'sub-cultures' - which were the focus of so much public anxiety and policy attention -were as divided by social class as the rest of UK society. Hall and Jefferson's work enabled a clear grasp of the ways in which cultural expressions mediated class divisions, and had their own power. 'Tuning in and turning on' to such expressions could be seen as an essential means of connection between the youth leader and groups of young people. For many years, courses drew not only on studies of group dynamics but also on cultural studies and radical deviancy studies as essential elements of the curriculum. In subsequent work, Hall (et al.) [17] were to identify the contradictions of this moment as a 'crisis of hegemony' as it developed through the prism of 'race'. 'The appearance of a renewed panic about race in the very moment of this intense polarisation of the political scene and just when the shift from a managed to a more coercive variant of consensus is occurring, cannot be wholly fortuitous.' [17]. The forces which supported a shift towards authoritarian populism, against which the new social movements were pitched, were already present in the late 1960 's, and already strongly focused around issues of race, nation and sexuality.

\section{The Group ......}

Some of the powerful struggles in practice as they were lived are present in the biography of Susan Atkins, one of only 17 women out of 145 students enrolled on the emergency programme for the training of youth leaders which ran at the National College in Leicester from 1961-1970. Susan, who went on to play a significant role as national chair in the development of the Community and Youth Workers Union (CYWU) and was instrumental in the establishment of the Women's Caucus of that union, gives an account of the influence of Peter Duke. Duke became the principal of the first National College for the Training of Youth Leaders, in 1964. With Peter, then the Warden of Oxford House, in Bethnal Green (whose nineteenth century origins lie with High Anglicanism and the Oxford Movement), Susan, as a young woman, was involved in theatricals, including 
the production of scenes from Shakespeare's 'A Midsummer Night's Dream'. Susan's account [18] of those years captures the continuity of the struggle in youth work education and training traditions between 'experience' and 'theory': Susan describes first 'learning on the job' as a young woman leading theatricals, then struggling to retain her place on the massively male-dominated emergency programme: a struggle in which, thankfully, she was successful. It was such struggles 'without a name' which prefigured the emergence of the Women's Liberation Movement. One expression of that movement was the formation of the Women's Caucus in the trade union.

With the emergence of professional education and training came the further development of theory to inform practice, and the term 'social education' became central to this. Initially the focus was on association and the dynamics of association: Bernard Davies, in his pamphlet 'From Social Education to Social and Life Skills Training' cites the following set of questions (drawn up for the Derbyshire Youth Service in 1963) as typical of the professional orientation to social education:

Is association in my club ... ... . . harmless ... ...?

Does association in my club introduce young people to new interests ... .. to responsibility?

Have any members shown increasing acceptance of themselves . . . . . .?

Are there members who have shown increasing acceptance of others ... ...?

Are there any who show increasing readiness to consort with members of the opposite sex in a relationship other than one of the forms of courtship? Do some members show increased ability to listen with attention to unfamiliar or accepted ideas ... . . . ? [19]

There is a resonance here with earlier definitions of 'social education' within youth work promoting the ability 'to entertain oneself; entertain a stranger; and entertain a new idea' [20]. Acceptance and non-judgementalism set the tone.

Group development was also seen as a fundamental element of community development:

The process of community development (or creation) is envisaged in two stages: the first, development within the groups themselves as the members become more knowledgeable people, more friendly and co-operative among themselves, and more able to conduct their business without outside help and guidance; and the second, development in the community at large as the characteristics developed within the groups influence the conduct of the members in their homes and in their neighbourhood. Thus, through the groups they sponsor the agencies aim to produced socialized and community-minded people, as well as knowledgeable people. They hope that leaders developed in their groups will later become leaders in community affairs [21].

Reg and Madge Batten (based at the Institute of Education, in London, after 'fieldwork' experience in Africa) influenced the curriculum of courses through their advocacy of a combination of directive and non-directive approaches. The non-directive approach can be understood as a move away from the moral certainties and colonial mastery inherent in earlier approaches, although the traces of colonial power remain in the assumption that 'socialised and community-minded people' need to be 'developed' rather than encountered, supported and resourced. 'The learning group' also became central to emerging approaches to adult education in the UK, as University Extra Mural Departments moved away from lecture courses towards an emphasis on recognising the experience of adults as a foundation for learning. This learning group became a central feature of courses both for part-time youth workers (the 'Bessey courses') [22] and for the original courses for full-time staff to achieve professional qualification. Often combined with a shift from 'lecturing' to 'group facilitation', the covert power of the tutor in the 'tutor group' on such courses became the focus for feminist and anti-racist critique in the 1980's. The scope (both for influence and for exploitation) afforded to the 'tutor as guru' in such apparently 'non-directive' groups became the material for much reflective critique from the 1980's onwards, including in the informal circulation among women of accounts of what was then newly termed 'sexual harassment.' 
The field of youth and community work became-in its own understanding-a space for group work and peer learning-and this was associated with self-development and autonomy for young people, in well-boundaried spaces, and with democratic rather than inherited forms of authority. The small group was a space for development and for the integration of learning. However, inherited patterns of authority had far from disappeared, and the disappointment and sometimes furious discontent caused by the ability of such apparently alternative spaces to remain deeply conventional in terms of power dynamics was persistently and acutely felt.

\section{The Personal Is Political: Experiential Learning That Starts from Discontent}

By the mid 1970's there was a significant flow (always at the margins) between the spaces being created in the new social movements-especially between student activists and the Women's Liberation Movement and Black Youth activism-and the pre-existing spaces of youth and community work. This was partly because these were spaces in which support for those living in the most disadvantaged neighbourhoods could be developed without recourse either to legal powers such as those possessed by social workers or the accompanying pathologising case work approaches and without involvement from the police. It was also because the social movements saw a significant politics in the social in the same moment (but often not in the same way) as youth work theorists saw a democratic educative potential in the same civil society spaces.

The significant new emphases emerging from the social movements was on the experience of power within the social and on the role of the small group in investigating and challenging hegemonic power in everyday life, whilst building the collective agentic power of participants. In the Women's Liberation Movement, the role of small groups was now seen as vital and as the central organising tool of the movement [23]. Practices of 'speaking bitterness' and of naming personal troubles as shared and potentially political issues were widely practised both formally, in consciousness-raising groups, and informally, in the many reading groups and campaigning groups which flourished, linked by magazines such as Spare Rib or Red Rag and by the publishing of pamphlets about emerging practices, theories and issues. All this was supported through newsletters and radical bookshops. These often-provided meeting spaces, alongside the meeting spaces emerging in women's centres and gay centres. One such newsletter was the 'Working with Girls Newsletter' [24]. The male dominance of the youth work sector was widely noted and discussed: this applied to the courses which trained youth workers. From the mid 1970's to the mid1980's the organising by feminists within youth work led to the formation, discussed earlier, of a women's caucus within the trade union, to regular conferences for women associated with the Working with Girls newsletter, and to the brief existence of the National Organisation for Work with Girls and Women, which argued for the development of a national training college specifically for women youth workers [25]. These networks developed organising strategies which disrupted any easy sense of the 'social' as a genderneutral space. Feminist women appointed to posts in training agencies (the precursors of today's degree programmes) began to attend the Training Agencies Group (TAG) and to raise issues of gender justice in that organisation, in ways which challenged the sense of an 'old boys club' in which the 'secretariat' (made up of the leaders of the small number of existing courses) shaped agendas and ran the show, even when the meetings happened in the ubiquitous 'democratic circle' of youth work training courses of that era.

The insistence on opportunities for women to meet autonomously within TAG meetings was an early example of a 'disruptive moment'; this was disruptive even though the regular annual conference was held on the weekend of the FA Cup Final and had always included a session dedicated to the watching of the match. In much the same way as newly established, feminist-inspired Girls Nights were often offered on Wednesday evenings, as Wednesdays were a 'football night', the possibility of women meeting at TAG during the match was offered, thus requiring some women to choose between their love of football and their politics. Such 'disruptive moments' are a hallmark of practice developed by 
social movements and interventions like these, drawn from the practice of the Women's Liberation Movement, and began to be theorised in ways which potentially transformed the meaning associated with 'experiential learning'.

One's social experience, and active enquiry into experience by experimenting with new patterns became the material for the exploration of social relations of oppression and subordination. Experiences in small groups could give glimpses of the potential for different ways of being in the world, become sources of solidarity and possible liberation, as well as offer discomforting insights into unnoticed and unthinking privilege. As Black Studies emerged alongside Women's Studies to challenge the curriculum and focus of training courses in youth and community work, the exploration and theorisation of imposed silences and subjugated knowledges made 'non-directive group work' deeply controversial in its power to non-directively sustain hegemonic power relationships. Instead, group work and experiential learning became the grounds for enquiry and for opening up the possibilities of change.

\section{Paulo Freire at West Hill College: An Emphasis on Critical Praxis as the Source of Transformation}

At first, there was considerable resistance in TAG to the inclusion of community work alongside youth work in courses. Subsequently, there was resistance to the inclusion of parttime and work-based courses alongside those historically based in colleges, polytechnics and universities. As the wave of new courses which emerged from the late 1980's onwards was for the most part dedicated to the recruitment of black workers, this suggested an exclusionary attitude towards those 'taking the experience route', which reinforced existing white hierarchies in relation to 'professional qualification.'

Important to all the social movements as they travelled in the spaces of community development, adult education and eventually youth work was the critical approach to education in the work of Paulo Freire [26]. His discussion of 'praxis' became central to understandings of the kind of practices we were engaged in.

'To speak a true word is to transform the world ... when a word is deprived of its dimension of action reflection automatically suffers as well and the word is changed into idle chatter ... into an alienated and alienating blah .... there is no transformation without action.

On the other hand, if action is emphasized exclusively to the detriment of reflection ... action for action's sake ... negates true praxis and makes dialogue impossible.' [26]

It is somewhat amazingly the case that Freire was part of a Conference on Community Development at West Hill College, Birmingham, in 1970. The influence of his work, and that of his critic and powerful advocate bell hooks, has been profound especially in those courses which associate themselves closely with community development. Critical pedagogy and engaged pedagogy offered the theoretical framework for practice.

Freirean approaches were by no means universally welcomed. In particular Freire's emphasis on the directive rather than the non-directive role of the educator was a source of much criticism, as was his revolutionary commitment to the transformation of social relations of oppression, which he termed 'liberation', 'transformation' and 'conversion.' Despite the fact that Freire argued that the educator needed to be directive of the process, not of the student, the sense was that the dialogue proposed by Freire could easily become mimicked as one led by Socrates in which 'yes Socrates/yes Paulo' was the only possible answer permitted to the learner. So, Freirean pedagogy—or 'critical pedagogy', as it came to be known-despite its commitment to dialogic relationships between partners in learning, was too often expressed and even experienced as an alternative form of mastery [27,28]. There was, too, a consistent fear within the world of youth work training and education, of too much emphasis on 'pedagogy' (and therefore education), with the consequent neglect of practices of association, collaboration and community-building, based on enthusiasm and enjoyment as much as on learning [29]. 'If I can't dance, I don't want to be part of your revolution.' 
The problem of too much emphasis on 'pedagogy' also related to the issues identified in 1980 by the authors of the London-Edinburgh Weekend Return Group's pamphlet 'In and Against the State.' 'Your resources we need. Your relations we don't.' [30]. There were significant unmet basic needs among both the young people and the older generations with whom youth and community workers engaged. At the same time, receiving resources from the State involved them in patterns of relationship they had rejected: pathologising communities; assessing individuals and families in terms of educational and parenting skills deficits; administering border controls on the access to opportunities.

Youth workers and other community educators too easily became 'street level bureaucrats' [31] even whilst also carrying traces (within the State) of the social struggles of the past. In a similar way, lecturers on courses also too easily became assessment bureaucrats, whilst carrying the same traces of social struggles in universities. Praxis and the critical linking of reflection and action was the only way to mitigate this in-built tendency. Praxis might mean drawing on university resources to support unfunded women's groups beyond the university; enabling students to undertake placements in newly emerging and not yet professionalised settings such as voluntary sector-based Black Youth Centres; supporting young people 'coming out' as gay in school contexts, and reflecting together across difference on the power of such actions. New thinking on 'diffractive practice' is strong in its critique of the way 'reflective journals' have become routinised and scripted as performances of the self. Reflective conversations in the context of new social movements, which emphasised the importance of conversations and coalitions across difference, and so were committed to the production of new praxis away from racism and sexism, may have been diffractive without knowing it.

\section{A Significant Text and a More Significant Practice: Defensive Spaces}

Between 1980 and 1982, the Youth Work Unit at the National Youth Bureau, led by Mary Marken, developed The Enfranchisement Development Project 'to consider the needs and therefore the position of young people in relation to organized society.' It drew heavily on work undertaken in a similar period by Steve Butters and Susan Newell [32], 'Realities of Training', in which Butters delineated what he termed 'the social education repertoire' (cultural adjustment, community development and institutional reform) and also posed the possibility of a critical break with social education towards a 'radical paradigm' (selfemancipation) in which workers aligned themselves with the youth against parental controls and fought the system, recognising that this would involve them in conflict, not consensus. The results of this project were published as 'Interpretation and Change: The Emerging Crisis of Purpose in Social Education', by Marion Leigh and Andy Smart.

In a moment of insight never far from the realities of practice, Leigh and Smart wrote: 'A number of workers would argue (on the basis of bitter experience of having apparently middle of the road non-controversial programmes of sex education and civics style political education subjected to intense political scrutiny) that the real critical break in practice can be found running through all the components of the Social Education Repertoire ... ' [33]. Perhaps the same critical break ran through the courses in universities. The challenges of the late 1970's and early 1980's, which were faced first on the streets, erupted in the form of a recognition of racism and exclusionary practice, subsequently enabling the development of Black Access courses as part of the struggle to establish a black presence and black perspectives within UK higher education. This struggle was felt in the Manchester course, for example, from the mid 1980's onwards, when student complaints about racism and the absence of black lecturers led to an HMI inspection which brought the course to the attention of the university authorities, who threatened the course with closure.

Leigh and Smart [33] end with a reflection on the future of concepts of professionalism in youth work. They sensed that the social democratic model associated with 'the social education repertoire' was under pressure, but found little support among practitioners for other, more radical and critical approaches to youth work, which seemed 'unprofessional.' This was especially the case for the 'oppositional approach', as it involved 'taking sides.' 
Yet throughout the book there is the insistent trace of the events that took place on British streets in 1981, after the long period of pressure on young black people, and young men especially, in the form of the 'sus' laws. In what came to be termed uprisings, young men (and some women) started to take their freedom into their own hands. Irvine Williams, from Moss Side Manchester (now youth work manager at the Hideaway a Moss Side Youth Centre), has spoken in a recent podcast of his experience as a young man [34]. He had been a member of Hideaway from age 14, in attendance at a centre in which there were many fights around the sound systems, boiling over among the youth as a result of the pressure from the hostile environment they were growing up in. In July 1981, discontents about unemployment and police brutality following Special Patrol Group's use of the 'sus law' erupted on the streets. At the age of 16, Irvine was picked up during the riots, arrested and taken to the Platt Fields police station in Manchester, just on the edge of the district. At this time, the youth workers all attended the police station to support the young people and were part of the crowd who came to the police station to free them. As a result of the support he received from youth workers in this way, at the age of 18, Irvine became a volunteer at the youth club, and began to associate with other black people running youth clubs in different parts of the country. He remembers powerfully his experience of support and guidance at that time from local youth workers, including Ann Rose, who became his tutor on the Youth and Community Work course at Manchester Polytechnic. This has informed his practice as a youth worker ever since. In this context, the paradigm which Leigh and Smart [32] describe as the 'oppositional paradigm' was far from unthinkable: it formed a basic practice of self- defence and mutual aid among young people who were especially vulnerable to what Leigh and Smart termed 'the encroaching non-welfare state.' Forty years before the coining of the phrase 'school to prison pipeline', youth workers and young people in Black communities such as Moss Side were already forging sustainable practices with which those offering professional formation to youth work professionals would struggle to engage. These were not State-led practices, they were not colonial practices and neither were they neutral, as those between young people and the authorities.

It was out of, and in response to, such experiences that the term 'Anti-Oppressive Practice' came to be coined. 'Race' as a prism through which to understand both the nature of the crisis in hegemony and the resolution of that crisis in new forms of authoritarian populism and in patterns of bureaucratisation and control continues to haunt the education of informal educators. Oppression, under its many names, has often seemed to be focussed in policing and the criminalisation of urban communities. The resistance and mutual aid practices of those communities remain a vital source for understanding what it might mean to be 'anti-oppressive', both including and beyond the experience of racism, as well as continuing to create often fragile civil society spaces which provide a defence for those young people consistently under attack from authoritarian populist responses to the continual crisis which occurs through the prism of 'race' in UK culture.

\section{New Managerialism and the National Occupational Standards: Paper Trails vs. Ethics}

According to Jean Spence [24], it was already the case in the late 1980's that the struggles of radical practitioners came to be re-interpreted by a managerial ethos in youth services which made commitments to anti-sexist and anti-racist work a managerial edict rather than a primary response to the needs and discontents of young people.

A good deal of energy went into institutional struggles to create a Statement of Purpose of a core curriculum for youth work in 1990, at the Second Ministerial Conference convened by the DES [35], which identified the task of the service as 'seeking to redress all forms of inequality and to ensure equality of opportunity for all young people'. It saw youth work as needing to operate 'through the challenging of oppressions such as racism and sexism and all those which spring from differences of culture race language sexual identity gender disability age religion and class'; And 'through the celebration of the diversity and strengths which arise from such differences.' 
Thus, the social struggles of the past left a trace within the documents of the State, or at least in documents aligned to the State. These documents were then to form the basis of 'National Occupational Standards' (NOS) [36] developed for youth work and the pre-degree level during the New Labour period and first published in 2002.

Between 1997 and 2010 the work of the Education and Training Standards Committee of the National Youth Agency and, by association, the work of TAG, became deeply embroiled with the necessity of creating national frameworks within which the work of youth workers, alongside that of other community educators, could be supported. Just as this applied to the education and training offered to voluntary and part-time youth and community workers at a pre-degree level, it also applied to degree programmes in universities. However, the professional field was largely concerned with specifying the skills and competences required of part-time youth workers, whilst the universities remained concerned with the requirement for all professional qualifications to be at the degree level by 2010 (and therefore in line with those awarded to social workers and teachers). It was as if every element of what had previously been a marginal but valued practice was now subject to minute assessment and the requirement of paper trails accrediting skills and competencies, which, like certificates and graduation ceremonies, became more elaborate in inverse proportion to their market or social value.

By 1999, the first Mapping of National Occupational Standards for Youth Work was completed. This period also saw the emergence of PAULO (named after Paulo Freire) as a National Training Organisation for Youth Work, Community Work and Adult Education [37]. PAULO was soon overtaken by a rationalisation process, and youth work' workforce development found itself positioned between Lifelong Learning UK (which it joined in 2005) and the powerful presence of the Children's Workforce Development Council. Just as the youth work workforce was now being 'integrated' into wider partnerships to pursue the 2003 Every Child Matters programme (2003) [38], so the skills and competencies required of Children's Workforce professionals became ever more generic and welfare/safeguarding-based.

It was during this period that I heard a committee report on the development of the National Occupational Standards [37]. When asked what had become of the commitment to anti-oppressive practice, the outsourced company responsible for the design of standards at that stage had taken the term to be a reference to good practice in the restraint of young people in residential settings.

Meanwhile, traces of earlier social movements were to be found in the higher education bureaucracy of the development of Subject Benchmarks. The development of the Subject Benchmark for Youth and Community Work began in 2006 [11]. Perhaps because of the distance from the re-organisation of the workforce, it was possible to retain for a while a sense of the presence of some distinctive commitments to enquiry, association and ethics in this statement. Professor Sara Banks of Durham University had worked with the National Youth Agency in 2000 to produce the Ethical Conduct in Youth Work: A Statement of Values and Principles [38], and it was now here that the strongest statements of values with significance for practice which challenges oppression were to be found.

It might seem that the claims of the social movements on the civil society space of youth work had been reduced to a subsection of a subsection in the National Occupational Standards: 'providing equality of opportunity [39]'.

\section{Without Conclusions}

A second article in this Special Issue [6] engages with the question of how these memories and archive might be living in the present moment, and what new forms of theorising and acting are being offered to youth work committed to understanding and unsettling oppression.

There is a good deal of work on the 'archive' currently, as an aspect of critical humanities. The writing of both these articles can be understood as framed by such an exploration. Karen Barad's [40] thinking on time/space entanglements is very significant for many writ- 
ers in this field. In this her work connects to that of earlier Marxist visionary thinkers-one of whom, Walter Benjamin, wrote vividly about the artist Paul Klee's 'Angel of History':

This is how one pictures the angel of history. His face is turned toward the past. Where we perceived a chain of events, he sees one single catastrophe which keeps piling wreckage and hurls it in front of his feet. The angel would like to stay, awaken the dead, and make whole what has been smashed. But a storm is blowing from Paradise; it has got caught in his wings with such violence that the angel can no longer close them. This storm irresistibly propels him into the future to which his back is turned, while the pile of debris before him grows skyward. The storm is what we call progress [41]. (Benjamin, 1940; 1959)

Such thinking suggests that time is not best understood as linear or progressive. The wreckage of oppression which continues to be piled up in what we can understand as 'one single catastrophe' faced by peoples across many generations. So, the catastrophes of police violence; or exclusion and violence based on gender and sexuality; or of segregated provision for disabled young people; or of poverty: these were not addressed 'once and for all' between 1970 and 1990, so that progress could be made. Rather, the storm continues to blow us back to the future, and the debris of earlier actions might become driftwood to hold on to as new actions to sustain life are taken. So 'memory work' is a method not primarily designed to provoke nostalgia or melancholy but to spur such new actions and a new praxis.

One way in which the new movements of the 21st century are being characterised is their focus on life and breathing as much as on voice and rights. A critical question that was present in the earlier movements mentioned here and which remains a necessary question is that of the relation between theory and experience, between ways of knowing and ways of being. 'Praxis' has been one term for this, a sense of the unity of action and thinking, as discussed in the work of Paulo Freire [26]. A further question, often provoked by feminist work on 'situated knowing', has been to consider how to avoid those forms of knowing and being that relegate other forms of knowing and being to redundancy and non-existence. In this essay I have sought to emphasise the contribution of unpublished practitioners who do not define themselves as scholars to the development of understandings of anti-oppressive practice in youth work. Therefore, the work with 'the archive' presented here is in itself an attempt to re-ignite those connections between different forms of knowing about informal education, as the new social movements of the current times alert us to the challenges of the current times.

Another current framing of this relation might be to emphasise what happens beneath language and concepts, what enables them, what sustains them. More and more we find ourselves drawn towards practices of care and salvage from the wreckage as the only practices strong enough to counter disaster capitalism and all its oppressive force. It is here, in these practices - in the resulting small-scale activity - that new ways of being-not of self-reflection or self-care, but of being in the world in difference, being in the world as relationality from the very start—can and do emerge, are already emerging. Youth work in community spaces is small enough and marginal enough to be part of that.

Funding: This research received no external funding.

Institutional Review Board Statement: Not applicable.

Informed Consent Statement: Not applicable.

Data Availability Statement: Not applicable.

Conflicts of Interest: The author declares no conflict of interest. 


\section{References}

1. Davies, B.; Taylor, T. On Critical Beginnings: How We Got to Where We Are. In Youth Work Global Futures; Bright, G., Pugh, C., Eds.; Brill Sense: Leiden, The Netherlands; Boston, MA, USA, 2019.

2. Thompson, N. Anti-Discriminatory Practice, 1st ed.; Palgrave Macmillan Basingstoke: London, UK, 1992.

3. Smith, M. Developing Youth Work: Informal Education, Mutual Aid and Popular Practice; Smith, M., Jeffs, T., Eds.; Open University Press: Milton Keynes, UK, 1988.

4. Vinen, R. The long 1968: Radical Protest and its Enemies; Allen Lane: London, UK, 2018.

5. Fisher, M. Capitalist Realism Is there No Alternative? Zero Books: London, UK, 2009.

6. Bowler, R.; Green, S.; Smith, C.; Woolley, L. (Re)Assembling Anti-Oppressive Practice Teachings in Youth and Community Work through Collective Biography (2). Educ. Sci. 2021, 11, 497. [CrossRef]

7. Haug, F. Female Sexualisation: A Collective Work of Memory; Verso: London, UK, 1987.

8. Davies, B.; Gannon, S. Doing Collective Biography; Open University Press: London, UK, 2006.

9. Tamboukou, M. Archives, genealogies and narratives in women workers' education. Women's Hist. Rev. 2020, 29. [CrossRef]

10. Batsleer, J. Feminist Webs: A Case Study of the Personal, Political and Professional in Youth Work. In Critical Practice with Children and Young People; Robb, M., Thomson, R., Eds.; Policy: Bristol, UK, 2010.

11. Subject Benchmark QAA Subject Benchmark Statements for Youth Work (3rd ed). The Quality Assurance Agency for Higher Education. 2019. Available online: https:/ / www.qaa.ac.uk/docs/qaa/subject-benchmark-statements/subject-benchmark-stat ement-youth-and-community-work.pdf?sfvrsn=5e35c881_4 (accessed on 14 June 2021).

12. Ministry of Education. Youth and Community Work in the $70^{\prime}$ 's; The Fairbairn-Milson Report; HMSO: London, UK, 1969.

13. Ministry of Education. The Youth Service in England and Wales; The Albermarle Report; HMSO: London, UK, 1960.

14. Duffy, C.A. The Laughter of Stafford Girls High. In Feminine Gospels; Picador: London, UK; Basingstoke, UK, 2002.

15. Hansen, S.; Jensen, J. The Little Red School Book; Pinter and Martin Ltd: London, UK, 1969.

16. Hall, S. Jefferson, T., Ed.; Resistance through Rituals. Youth Subcultures in Postwar Britain; Routledge: London, UK, 1975.

17. Hall, S.; Critcher, C.; Jefferson, T.; Clarke, J.; Roberts, B. Policing the Crisis: Mugging, the State and Law and Order; Macmillan: London, UK, 1978.

18. Atkins, S. Albemarle pioneer and Principal of the National College, Peter Duke RIP. 2018. Available online: https://inde fenceofyouthwork.com/2018/01/22/albemarle-pioneer-and-principal-of-the-national-college-peter-duke-rip/ (accessed on 14 June 2021).

19. Davies, B. Whose Interests? From Social Education to Social and Life Skills Training; NYB: Leicester, UK, 1979.

20. McAlister Brew, J. Informal Education Adventures and Reflections; Faber: London, UK, 1946.

21. Batten, T.R. Communities and Their Development: An Introductory Study with Special Reference to the Tropics, 5th ed.; Oxford University Press: Oxford, UK, 1957.

22. Ministry of Education. The Training of Part-Time Youth Leaders and Assistants (The Bessey Report); HMSO: London, UK, 1962.

23. Juliet Mitchell: Looking back at Woman's Estate. Available online: https://www.versobooks.com/blogs/1836-juliet-mitchell-lo oking-back-at-woman-s-estate (accessed on 11 May 2021).

24. Spence, J. Collecting Women's Lives. The Challenge of Feminism in UK Youth Work in the 1970's and 80's. Women's Hist. Rev. 2010, 19, 159-176. [CrossRef]

25. Batsleer, J. Youth Working with Girls and Young Women in Community Settings. A Feminist Perspective; Ashgate: Farnham, UK, 2014.

26. Freire, P. Pedagogy of the Oppressed; Continuum: London, UK; New York, NY, USA, 1970.

27. Lather, P. Getting Smart: Feminist Research and Pedagogy with/in the Postmodern; Routledge: New York, NY, USA, 1991.

28. Ellsworth, E. Why doesn't this feel empowering? Working through the repressive myths of critical pedagogy. In Feminism and Critical Pedagogy; Luke, C., Gore, J., Eds.; Routledge: New York, NY, USA, 1992.

29. Robertson, S. Youth Clubs: Association, Participation, Friendship and Fun; Russell House Press: Nottingham, UK, 1995.

30. London to Edinburgh Weekend Return Group. In and Against the State: Discussion Notes for Socialists; Pluto: London, UK, 1980.

31. Lipsky, M. Street Level Bureaucracy: Dilemmas of the Individual in Public Services; Russell Sage Foundation: New York, NY, USA, 2010.

32. Butters, S.; Newell, S. Realities of Training: A Review of the Training of Adults Who Volunteer to Work with Young People in the Youth and Community Services; National Youth Bureau: Leicester, UK, 1978.

33. Leigh, M.; Smart, A. Interpretation and Change: The Emerging Crisis of Purpose in Social Education; NYB: Leicester, UK, 1985.

34. Family and friendship for over fifty years, the Hideaway Youth Project tells a magical Moss Side story. Available online: https:// www.manchestere39eningnews.co.uk/news/greater-manchester-news/hideaway-radio-documentary-moss-side-18146831 (accessed on 1 June 2021).

35. National Youth Bureau. Towards a Core Curriculum-The Next Steps: Comments and Recommendations of the Ministerial Conferences Steering Group; Para 22, 32; NYB: Leicester, UK, 1990.

36. National Occupational Standards and English Youth Work Policy-New Document Published I NYA: Leicester. Available online: https:/ / nya.org.uk/resource/national-occupational-standards/ (accessed on 14 May 2021).

37. HM Treasury. Every Child Matters; Green Paper; CM 5860; HMSO: London, UK, 2003.

38. National Youth Agency. Ethical Conduct in Youth Work. 2004. Available online: https://nya.org.uk/static/4824723ae8719d1f67 c7519f55837ac2/Ethical_conduct_in_Youth-Work-1.pdf (accessed on 14 June 2021). 
39. CLD. National Occupational Standards YouthWork. CLD Standards Council. 2019. Available online: https://cldstandardscounci l.org.uk/resources/standards-and-benchmarks/national-occupational-standards/ (accessed on 14 May 2021).

40. Barad, K. Meeting the Universe Halfway; Duke Press: Durham, NC, USA, 2007.

41. Benjamin, W. Theses on the Philosophy of History. In Illuminations; Knopf: New York, NY, USA, 1970. 